\title{
COHERENCE SCORES AND COHERENCE LEVEL: MODIFICATION EFFECTS OF HYDRO-AROMATHERAPY AND MINDFULNESS MEDITATION ON PATIENTS SUFFERING FROM INFLAMMATORY RHEUMATIC DISEASES
}

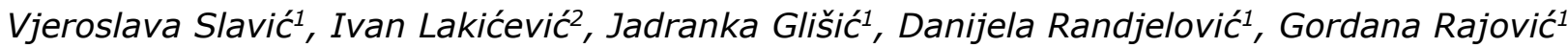

\begin{abstract}
Heart rate variability (HRV) and coherence score (CS) or coherent heart rhythm pattern are a validated method to establish autonomic nervous system (ANS) activity.

The aim of this research was to assess the modifications of CSs in a sample of patients suffering from inflammatory rheumatic diseases during their physical treatment and rehabilitation based on natural factors as well as hydro-aromatherapy and meditation.

This study included 44 Norwegian patients with confirmed diagnosis of inflammatory rheumatic diseases during four weeks of physical treatment and rehabilitation at the Institute "Dr Simo Milošević" Igalo, Montenegro. They were divided into two groups: (1) experimental ( $n$ $=22)$ and $(2)$ control $(n=22)$. All the patients received the standard protocol based on natural healing mud and mineral water. However, the patients in the experimental group had additional hydro-aromatherapy (mineral water enriched with essential oils of lavender, orange and lemon) and meditation. The emWave Pro machine measured CS before and after the treatment. There were three coherence levels (CL): low, medium and high. Low reflected the amount of time in which there was no wavelike activity, medium some wavelike activity, and high a considerable amount of wavelike activity in the HRV tracing.

After the treatment, the CS was found to be significantly higher in the experimental group than in the control group $(p<0.015)$. Simultaneously, the high $C L$ was significantly higher in the experimental group $(p<0.026)$, and the low CL was significantly lower in the control group $(p<0.017)$. Comparison of the obtained CLs between the experimental and control groups after treatment showed that only the medium $C L$ was statistically different $(\mathrm{p}<$ 0.009).
\end{abstract}

Standard protocol at the Institute Igalo with the addition of hydro-aromatherapy and meditation significantly improved the ANS activity of patients suffering from inflammatory rheumatic diseases.

Acta Medica Medianae 2021;60(4):09-15.

Key words: coherence score, coherence levels, inflammatory rheumatic diseases

${ }^{1}$ Institute "Dr Simo Milošević" Igalo, Igalo, Montenegro

2Black Dog Institute Randwick, Randwick, Australia

Contact: Vjeroslava Slavić

5 Sava Ilića Str., 85347 Igalo, Montenegro

E-mail: drvjeroslavaslavic@gmail.com

\section{Introduction}

Diseases, especially of a chronic nature, such as chronic inflammatory rheumatic diseases (CIRDs), often cause major changes in the way a person functions and affect all aspects of life (1). The sense of coherence (SOC) concept was initially used to describe a person's capacity to respond to stressful situations, such as chronic illness (2). It was subsequently replaced by physiological coherence (PC), a term that describes the degree of order, harmony and stability in rhythmic activities within living systems over any given time period (3).

In the human body, the heart is the most consistent and dynamic generator of rhythmic information patterns, which are measured as heart rate (HR) on a beat-to-beat basis. HR fluctuations result from the complex nonlinear interactions of several physiological systems. HR variability (HRV) is thus considered a measure of neurocardiac function, which reflects the heart-brain interactions and autonomic nervous system (ANS) dynamics $(4,5)$. In this complex network, the vagal nerve (VN) plays a central role, being the longest cranial nerve in the human body, containing about $75 \%$ of the parasympathetic (PSY) fibres. Of these VN fibres, 80$90 \%$ are afferent, and they generate the appropriate 
autonomic responses via central reflex pathways (6). Simultaneously, the VN efferent fibres dominate in cardiac control (7). Therefore, HR best reflects the relative balance in the ANS dynamics (8).

Autonomic imbalance (AI), defined as an increased HR and a decreased HRV, has attracted the attention of researchers. According to published studies, AI is associated with increased morbidity and mortality in patients with various diseases (9), and it has been implicated as a key underlying feature of several inflammatory arthritides (10). The association of AI with the onset of rheumatoid arthritis (RA) could also be important for other immune-mediated inflammatory diseases (11). To further understand this phenomenon, AI has been defined as an immunomodulatory or inflammatory reflex. In this reflex, activation of the VN plays an integral role in the downregulation of inflammation (12). However, decreased VN function precedes the development of several risk factors for cardiovascular disease (13).

It seems that the inflammatory or immunomodulatory reflex, an integral aspect of the pathogenesis of inflammatory diseases mediated by the immune system, may be altered or modified by neuromodulation for the benefit of the patient (14). Mindfulness meditation (MM) is one of the non-invasive neuromodulation modalities aimed at enhancing parasympathetic tone (15). Recent well-controlled studies have indicated that MM training may reduce the concentration of inflammatory markers, such as C-reactive protein (CRP) and interleukin 6 (IL-6) (16).

Published studies have shown that aromatic oils (AOs) can also serve as stimulus for the noninvasive neuromodulation of the immunomodulatory reflex. Through the olfactory stimulus, AOs have various effects on physiological functions (17), especially the ANS (18). Their beneficial effects are not limited to only the olfactory system because they can enter the bloodstream by absorption through the skin and nasal and/or oral mucous membranes. In addition, as lyophilic substances, they can reach the brain. Consequently, AOs cause broad-spectrum effects, including brain wave activity and the normalisation of cortisol, dopamine and norepinephrine levels, as well as the CD4/CD8 lymphocyte ratio (19-22).

The aim of this research was to assess the modification of coherence score (CS) and coherence level $(C L)$ in a sample of patients suffering from inflammatory rheumatoid diseases during their physical treatment and rehabilitation based on natural factors as well as hydro-aromatherapy and meditation.

\section{Materials and methods}

This study included 44 Norwegian patients with confirmed diagnosis of CIRD recruited by the Section for Climate Therapy, Oslo University Hospital, Norway, and subjected to four weeks of physical treatment and rehabilitation at the Institute "Dr Simo Milošević" Igalo, Montenegro in August and
September 2018. The CIRD implied following diagnosis: rheumatoid arthritis (RA), ankylosing spondylitis (AS) and psoriatic arthritis (PSA). They were divided into two groups:

(1) experimental $(n=22)$ and

(2) control $(n=22)$.

The groups did not differ in average age and disease duration (50y vs. $55 y$; $14 y$ vs. $17 y$ ). All the patients included in the study were in remission of the underlying disease with low disease activity based on clinical and laboratory parameters. During treatment at the Institute, all the patients were taking prescribed rheumatological therapy. So, there were no contraindications for the use of the standard protocol, based on natural healing mud and mineral water. Natural healing mud is characterized by high mineral contents and biologically active substances extracted from Igalo Bay. It is applied on certain body parts (except at the fore part of the thoraxheart and head) at a temperature of $42-45^{\circ} \mathrm{C}$. Mineral water is of natural origin from several springs and in its content is dominated by minerals and bioactive substances. Water is used when heated at $36-38^{\circ} \mathrm{C}$.

The patients in the experimental group had additional hydro-aromatherapy, which comprised mineral whirlpool bath enriched with essential oils of lavender, orange and lemon, every other day, as well as $20 \mathrm{~min}$ of mindfulness-type meditation five days per week.

The emWave Pro device was used to measure the CSs before and after the four weeks of treatment. As a heart-rate monitoring system, the device used a pulse sensor (on the subject's earlobe) and breath pacer (on the subject's clothes) plugged into a computer, collected pulse data and translated coherence information into graphics displayed on computer screen. The device gave readings with regard to date, time, session duration, coherence score, average heart rate, challenge level and coherence rate. During each session measurements were continuously monitored and were displayed as numbers, coloured bars, and curves.

Physiologically, the coherence state was reflected in the presence of a smooth sine-wave-like pattern in the HRV tracing. The total CSs ranged as follows: basic (0.5-1), good (1-2), very good (2-3) and excellent $(+3)$. There were three levels of CS: low, medium and high. A low CS reflected the amount of time during which there was no wavelike activity, medium indicated some wavelike activity, and high reflected a considerable amount of wavelike activity in the HRV tracing (22). Testing on the emWave Pro machine took $15 \mathrm{~min}$ in an air-conditioned room and in silence. Patients took a sitting position. The device was set to a mid-level challenge for testing. The study was approved by the Ethical Committee of the Faculty of Medicine, University of Montenegro.

The results were statistically analysed in IBM SPSS Statistics, Version 23.0 software. The analyses included descriptive statistics and the paired t-test. A $p$ value of $<0.05$ was considered statistically significant. 


\section{Results}

The analysed groups of patients were matched by age and disease duration. However, females were more represented in both groups (experimental group, 60.9\%; control group, 73.9\%). The standard protocol significantly reduced HRs in the control group $(t=2.631 ; p<0.016)$, but not in the experimental group (Table 1 ).

The average CSs in the experimental group after four weeks of treatment were significantly higher $(t=2.663$; $p<0.015)$ than those in the con- trol group. However, the differences in the CS ranges obtained before and after treatment were not statistically significant (Table 2).

The following results were obtained in the groups after analysing the impact of the treatment on the CS levels. First, high CS levels significantly increased in the experimental group $(t=1.926$; $p<$ 0.026); second, low CS levels significantly decreased in the control group ( $t=2.795$; $p<0.017$ ); third, the medium CS levels were significantly lower in the experimental group than in the control group ( $\mathrm{t}=$ 2.923; $p<0.009$ ) (Table 3).

Table 1. Heart rates before and after treatment in the experimental and control groups (mean \pm SD)

\begin{tabular}{||c||c|c|c||}
\hline HR (mean \pm SD) & Before treatment & After treatment & $\mathrm{p}<$ \\
\hline \hline Experimental group $(\mathrm{n}=22)$ & $74.86 \pm 11.62$ & $73.76 \pm 10.87$ & n.s. \\
\hline Control group $(\mathrm{n}=22)$ & $77.00 \pm 13.54$ & $72.10 \pm 11.04$ & 0.016 \\
\hline
\end{tabular}

Table 2. Coherence scores and Coherence score ranges before and after treatment in the experimental and control groups

\begin{tabular}{||c|c|c|c||}
\hline Experimental group $(\mathrm{n}=22)$ & Before treatment & After treatment & $\mathrm{p}<$ \\
\hline \hline Coherence score (mean \pm SD) & $0.9619 \pm 0.2941$ & $1.2524 \pm 0.7075$ & 0.015 \\
\hline Coherence range (\%) & & & \\
Basic & 50 & 25 & n.s. \\
Good & 50 & 60 & n.s. \\
Very good & 0 & 10 & n.s. \\
Excellent & 0 & 5 & n.s. \\
\hline \hline Control group ( $\mathrm{n}=22)$ & Before treatment & After treatment & $\mathrm{p}<$ \\
\hline \hline Coherence score (mean \pm SD) & $1.0200 \pm 0.4034$ & $1.2850 \pm 0.6327$ & n.s. \\
\hline Coherence range (\%) & & & \\
Basic & 63.16 & 37.37 & n.s. \\
Good & 36.84 & 10.53 & n.s. \\
Very good & 0 & 5.26 & n.s. \\
Excellent & 0 & & n.s. \\
\hline
\end{tabular}

Table 3. Coherence score levels before and after treatment in the experimental and control groups (mean value \pm SD)

\begin{tabular}{||c|c|c|c||}
\hline Experimental group $(\mathrm{n}=22)$ & Before treatment & After treatment & $\mathrm{p}<$ \\
\hline \hline Low & $46.9048 \pm 16.2077$ & $40.3810 \pm 21.2402$ & $\mathrm{n} . \mathrm{s.}$ \\
Medium & $42 \pm 11.9121$ & $39.2857 \pm 9.8242$ & $\mathrm{n} . \mathrm{s}$. \\
High & $11.0952 \pm 7.2381$ & $20.3333 \pm 21.5414$ & 0.026 \\
\hline \hline Control group $(\mathrm{n}=22)$ & Before treatment & After treatment & $\mathrm{p}<$ \\
\hline \hline Low & $43.9500 \pm 18.4604$ & $32.25 \pm 18.4872$ & 0.017 \\
Medium & $40.4 \pm 12.0499$ & $48.35 \pm 15.9317$ & n.s. \\
High & $15.85 \pm 11.2216$ & $19.5 \pm 20.1847$ & n.s. \\
\hline
\end{tabular}




\section{Discussion}

We investigated the effectiveness of hydroaromatherapy (HAT) and MM, as well as physical treatment and rehabilitation, on the possible noninvasive neuromodulation of ANS in patients with established CIRD. This study was carried out at the Institute Igalo, which is known for its natural factors and more than 70 years of experience in the physical treatment and rehabilitation of patients with rheumatological diseases. Hence, the focus was on the determination of physiological stress or HRV as a simple noninvasive measurement of autonomic balance through changes in CS levels.

It has long been postulated that ANS, particularly the PSY, modulates the immune system in chronic inflammatory diseases. It also has antinociceptive effects (23). Indeed, the PSY maintains the homeostasis of the psycho-neuroendocrine-immune system through the afferent (to the hypothalamus, central ANS, limbic system, thalamus and cortex) and efferent (cholinergic anti-inflammatory) pathways (24).

According to the literature, AOs have a powerful neuromodulatory effect. Furthermore, their ingredients have shown significant pharmacological activities, including anti-inflammatory properties (25), such as the reduction of oxygen and nitrogen radicals and the expression of proinflammatory cytokines, during chronic inflammation (26). Thus, lavender oil was confirmed to suppress inflammation and to restore antioxidative enzyme activity (27).

Orange and lemon oils have central and peripheral antinociceptive effects in addition to their anti-inflammatory effect (28). In our study, aromatic oils of lavender, orange and lemon were applied during HAT, which, in addition to transcutaneous absorption, have significant effects through the nasal mucosa.

Another important neuromodulation tool, MM, was used in this study. Recent well-controlled studies have indicated that MM training could reduce inflammatory markers, such as CRP and IL-6 (29), cortisol, blood pressure, HR and tumour necrosis factor alpha (TNF $\alpha$ ) (30). Despite the growing popularity of $\mathrm{MM}$, the neurobiological mechanisms by which MM might affect stress are not well understood (31).

Previous studies have indicated that improving the coherence state may lead to improvements in patients suffering from CIRD (8). Thus, four weeks of treatment by HAT and MM, in addition to the standard rehabilitation protocol, resulted in significantly improved CS and its levels. Our goal was to understand the possible neuromodulatory mechanisms of HAT and MM by analysing CS and its levels. HAT and MM, along with the standard rehabilitation protocol, led to a significant increase in the high CS level. At the same time, standard rehabilitation protocols alone, based on natural factors, significantly reduced the low CS level. According to the literature, the low CS level reflects hormonal (e.g., renin-angiotensin-aldosterone activity) and thermoregulatory effects on the heart. A medium CS level is modulated by the sympathicus (SY) and PSYs, and it is associated with baroreceptor activity. A high CS level is modulated by the PSYs, and it is related to respiration (32-34). This means that HAT and MM, with the standard protocol, enhances PSY activities, whereas the sole use of the standard protocol enhances SY activities, including HR. Furthermore, a statistically significant decrease in the CS levels in the experimental group indicates that HAT and MM have significant effects on PSY activity.

This pilot study has highlighted the importance of activating the innate healing mechanism underlying symptom suppression through the noninvasive neuromodulation of the ANS in order to improve the CS levels. Thus far, the importance of the innate healing mechanism has not been fully appreciated (22).

Despite recent advances in treatment optimization using biological and immunomodulatory therapies in rheumatologic patients, their use has been accompanied by significant side effects and an increase in the prevalence of comorbidities. The common protocols for physical treatment and rehabilitation are aimed at increasing mobility, reducing pain and, thus, improving quality of life. CIRD is characterized by disorders of the immune system, as well as oxidative and metabolic stress, which affect the overall CS levels.

The results of this study indicate that HAT and $\mathrm{MM}$, along with the natural factors at the Institute Igalo, significantly improved ANS activity, especially PSY, in patients suffering from inflammatory rheumatoid diseases.

\section{Acknowledgement}

This work was financed by the project No MNA-INO-2017-03 by Minstry of Science, Montenegro. 


\section{References}

1. Wysocka-Skurska I, Sierakowska M, Kułak W. Evaluation of quality of life in chronic, progressing rheumatic diseases based on the example of osteoarthritis and rheumatoid arthritis. Clin Interv Aging 2016;11:174150. [CrossRef] [PubMed]

2. Antonovsky A. Unravelling the mystery of health: how people manage stress and stay well. San Francisco (CA): Jossey-Bass; 1987.

3. Tiller WA, McCraty R, Atkinsom M. Cardiac coherence: a new non-invasive measure of autonomic nervous system order. Alter Ther Health Med 1996;2:52-65. [PubMed]

4. Shaffer F, McCraty R, Zerr CL. A healthy heart is not a metronome: an integrative review of the heart's anatomy and heart rate variability. Front Psychol 2014;5:1040. [CrossRef] [PubMed]

5. McCraty $R$, Atkinson $M$, Tomasino $D$, Bradley $R T$, editors. The coherent heart: Heart-Brain interactions, psychophysiological coherence, and the emergence of system-wide order. Boulder Creek, CA: Institute of Heartmath; 2009.

6. Berthoud HR, Neuhuber WL. Functional and chemical anatomy of the afferent vagal system. Auton Neurosci 2000;85(1-3):1-17. [CrossRef] [PubMed]

7. Levy MN. Autonomic interactions in cardiac control. Ann N Y Acad Sci 1990;601:209-21.

[CrossRef] [PubMed]

8. McCraty $R$, Shaffer F. Heart rate variability: new perspectives on physiological mechanisms, assessment of self-regulatory capacity and health risk. Glob Adv Health Med 2015;4(1):46-60. [CrossRef] [PubMed]

9. Inoue $T$, Iseki $K$, Ohya $Y$. Heart rate as a possible therapeutic guide for prevention of cardiovascular disease. Hypert Res 2013;36(10):838-44.

[CrossRef] [PubMed]

10. Syngle A, Verma I, Garg N, Krishan P. Autonomic dysfunction in psoriatic arthritis. Clin Rheumatol 2013; 19(3):1059-64. [CrossRef] [PubMed]

11. Koopman FA, Tang MW, Vermeij J, Hair MJ, Choi IY, Vervoordeldonk $\mathrm{MJ}$, et al. Autonomic dysfunction precedes development of rheumatoid arthritis: a prospective cohort study. EbioMed 2016;16(6):231-7. [CrossRef] [PubMed]

12. Tracey KJ. Reflex control of immunity. Nat Rev Immunol 2009;9(6):418-28. [CrossRef] [PubMed]

13. Thayer JF, Lane RD. The role of vagal function in the risk for cardiovascular disease and mortality. Biol Psychol 2007;74:224-42. [CrossRef] [PubMed]

14. Yang EJ, Beck KM, Koo J. Neuromodulation in psoriasis and psoriatic arthritis. Ann Chron Dis 2018;2(1):1003.

15. Ben-Menachem E, Hellstrom K, Verstappen D. Analysis of direct hospital cost before and after 18 months after treatment with vagus nerve stimulation therapy in 43 patients. Neurology 2002;59(6 suppl 4):S44-7. [CrossRef] [PubMed]

16. Creswell JD, Taren AA, Lindsay EK, Greco CM, Gianaros PJ, Fairdrieve A, et al. Alterations in restingstate functional connectivity link Mindfulness Meditation with reduced Inteleukin-6: a randomized controlled trial. Biol Psych 2016;80:53-61. [CrossRef] [PubMed]

17. Liu Y, Liebertwirth $C$, Jia X, Curtis JT, Meredith M, Wang ZX. Chemosensory cues affect amygdaloidal neurogenesis and alter behaviors in the socially monogamous prairie vole. Eur J Neurosci 2014;39: 1632-41. [CrossRef] [PubMed]

18. McCabe C, Rolls ET. Umami: a delicious flavor formed by convergence pathways in the human brain. Eur J Neurosci 2007;25:1855-64. [CrossRef] [PubMed]

19. Sayorwan W, Siripornpanich V, Piriyapunyaporn T, Hongratanaworakit T, Kotchabhakdi N, Ruangrungsi $\mathrm{N}$. The effects of lavender oil inhalation on emotional states, autonomic nervous system and brain electrical activity. J Med Assoc Thai 2012;95(4):598-606. [PubMed]

20. Atsumi T, Tonosaki K. Smelling lavender and rosemary increases free radical scavenging activity and decrease cortisol level in saliva. Psychiatry 2007;150: 89-6. [CrossRef] [PubMed]

21. Komori T, Fujiwara R, Tanida M. Effects of citrus fragrance on immune function and depressive states. Neuroimmunomodulation 1995;2:174-80. [CrossRef] [PubMed]

22. Kiecolt-Glaser JK, Graham JE, Malarkey WB. Olfactory influences on mood and autonomic, endocrine and immune function. Psychoneuroendocrinology 2008; 33:328-39. [CrossRef] [PubMed]

23. Gerbard PL, Jacob VE, Stevens L, Bosworth BP, Chabouni F, DeFillipis EM, et al. The effect of breathing, movement and meditation on psychological and physical symptoms and inflammatory biomarkers in inflammatory bowel disease: a randomized controlled trial. Inflamm Bowel Dis 2015;21:2886-96. [CrossRef] [PubMed]

24. Streeter CC, Gerbard PL, Saper RB. Effects of yoga on the autonomic nervous system, gamma-aminobutyric acid, and allostasis in epilepsy, depression and posttraumatic stress disorder. Med Hypotheses 2012;78: 571-9. [CrossRef] [PubMed]

25. Miguel MG. Antioxidant and anti-inflammatory activities of essential oils: a short review. Molecules 2010; 15(12):9252-87. [CrossRef] [PubMed]

26. de Lavor EM, Cavalcante Fernandes AW, Andrade Teles RB, Pereira Leal AEB, de Oliveira Júnior RG, e Silva MG et al. Essential oils and their major compounds in the treatment of chronic inflammation: a review of antioxidant potential in preclinical studies and molecular mechanisms. Oxid Med Cell Longev 2018;2018:Article ID 6468593. [CrossRef] [PubMed]

27. Aboutaleba N, Jamalia H, Abolhasanib M, Pazoki Toroudia H. Lavender oil (Lavandula angustifolia) attenuates renal ischemia/reperfusion injury in rats through suppression of inflammation, oxidative stress and apoptosis. Biomed Pharmacother 2019;110:9-19. [CrossRef] [PubMed]

28. Khodabakhsh $P$, Shafaroodi $H$, Asgarpanah J. Analgesic and anti-inflammatory activities of Citrus aurantium L. blossoms essential oil (neroli): involvement of the nitric oxide/cyclic-guanosine monophosphate pathway. J Nat Med 2015;69:324-31. [CrossRef] [PubMed]

29. Creswell JD, Taren AA, Linsay EK, Greco CM, Gianaros $\mathrm{PJ}$, Fairgrive $\mathrm{A}$, et al. Alterations in resting-state functional connectivity link mindfulness meditation with reduced interleukin-6: a randomized controlled trial. Biol Psych 2016;80:53-61. [CrossRef] [PubMed]

30. Pascoe MC, Thompson DR, Jenkins ZM, Ski CF. Mindfulness mediates the physiological markers of stress: systematic review and meta-analysis. J of Psych Res 2017;95:156-78. [CrossRef] [PubMed] 
31. Pascoe M, Bauer I. A systematic review of randomised control trials examining the effects of mindfulness on stress and anxious symptomatology. Anxiety Disord 2016;68:270-82. [CrossRef] [PubMed]

32. Robertson D, Biaggioni I, editors. Primer on the autonomic nervous system. San Diego: Academic; 2012.

33. Hildreth CM, Goodchild AK, Phillips JK. Insight into autonomic nervous system control of heart rate in the rat using analysis of heart rate variability and baroreflex sensitivity. In: Pilowsky OM, Farnham MMJ, Fong AY, editors. Stimulation and inhibition of neurons. New York: Humana; 2013:203-23.

[CrossRef]

34. Zygmunt A, Stanczyk J. Methods of evaluation of autonomic nervous system function. Arch Med Sci AMS 2010;6(1):11-8. [CrossRef] [PubMed] 


\title{
BODOVI KOHERENCIJE I NIVO KOHERENCIJE: MODIFIKACIONI EFEKTI HIDROAROMATERAPIJE I MEDITACIJE PUNE SVESNOSTI KOD BOLESNIKA SA UPALNIM REUMATOIDNIM BOLESTIMA
}

\author{
Vjeroslava Slavić ${ }^{1}$, Ivan Lakićević ${ }^{2}$, Jadranka Glišićc ${ }^{1}$ Danijela Ranđelović ${ }^{1}$, Gordana Rajović ${ }^{1}$
}

\author{
${ }^{1}$ Institut "Dr Simo Milošević" Igalo, Igalo, Crna Gora \\ ${ }^{2}$ Black Dog Institut Randwick, Randwick, Australija \\ Kontakt: Vjeroslava Slavić \\ Sava Ilića 5, 85347 Igalo, Crna Gora \\ E-mail: drvjeroslavaslavic@gmail.com
}

Nedavno su varijabilnost otkucaja srca (HRV) i koherentni rezultat (CS) ili koherentan obrazac srčanog ritma prihvaćene kao validirane metode za uspostavljanje aktivnosti autonomnog nervnog sistema (ANS).

Cilj ovog istraživanja je proceniti modifikacije CS-a u uzorku bolesnika koji pate od upalnih reumatoidnih bolesti, tokom njihovog fizikalnog lečenja i rehabilitacije, na osnovu prirodnih faktora, kao i hidroaromaterapije i meditacije.

Ovo istraživanje obuhvatilo je 44 norveška bolesnika sa potvrđenom dijagnozom inflamatornih reumatoidnih bolesti, tokom četiri nedelje fizikalnog lečenja i rehabilitacije u Institutu "Dr Simo Milošević" Igalo, Crna Gora. Bolesnici su podeljeni u dve grupe: (1) eksperimentalna $(n=22)$ i (2) kontrolna $(n=22)$. Svi bolesnici dobili su standardni protokol zasnovan na prirodnom lekovitom blatu i mineralnoj vodi. Međutim, bolesnici u eksperimentalnoj grupi imali su dodatnu hidroaromaterapiju (mineralna voda obogaćena eteričnim uljima lavande, narandže i limuna) i meditaciju. Mašina emVave Pro merila je CS, pre i posle tretmana. Postojala su tri nivoa koherentnosti $(C L)$ : niski, srednji i visoki. Nizak nivo koherentnosti odražavao je količinu vremena u kojem nije bilo talasne aktivnosti, srednji nivo imao je neku talasnu aktivnost, a visoki nivo koherentnosti imao je značajnu količinu talasne aktivnosti u praćenju $H R V$-a.

Nakon tretmana, utvrđeno je da je CS značajno veći kod bolesnika iz eksperimentalne grupe nego kod bolesnika iz kontrolne grupe $(p<0,015)$. Istovremeno, visoka $C L$ bila je značajno veća kod bolesnika iz eksperimentalne grupe $(p<0,026)$, a niska $C L$ bila je značajno niža kod bolesnika iz kontrolne grupe $(p<0,017)$. Poređenje dobijenih $C L$ između eksperimentalne i kontrolne grupe nakon tretmana pokazalo je da je samo $C L$ medijuma statistički različito $(p<0,009)$.

Standardni protokol u Institutu Igalo uz dodatak hidroaromaterapije i meditacije značajno je poboljšao aktivnost ANS bolesnika koji pate od upalnih reumatoidnih bolesti.

Acta Medica Medianae 2021;60(4):09-15. bolesti

Ključne reči: ocena koherentnosti, nivoi koherentnosti, inflamatorne reumatoidne 